\title{
ФАКТОРЫ, ВЛИЯЮЩИЕ НА СОДЕРЖАНИЕ КАННАБИДИОЛА В РАСТЕНИЯХ КОНОПЛИ (Cannabis sativa L.)*
}

\section{С.В. ГРИГОРЬЕВ 1 , К.В. ИЛЛАРИОНОВА²}

Производство промышленной конопли и продуктов ее переработки (текстиля, семян и масла для функционального питания, фармацевтических препаратов) - интенсивно развивающиеся отрасли мирового сельскохозяйственного производства. В Российской Федерации в Государственном реестре селекционных достижений, допущенных к использованию, зарегистрированы 27 сортов и гибридов конопли универсального направления продуктивности, однако нет сортов для получения каннабидиола (КБД) - фитоканнабиноида, который не обладает наркотической активностью, не относится к наркотическим средствам, не внесен в список наркотических средств Единой Конвенции ООН о наркотиках, но востребован для производства медицинских препаратов. В настоящее время существует необходимость в сортах фармацевтической специализации (КБД-сортах). В своем исследовании мы впервые выделили формы конопли с признаками контрастно высокого содержания КБД (более $9 \%$ ) и следовых количеств $\Delta^{9}$-тетрагидроканнабинола (ТГК) - основного психотропного каннабиноида. Целью работы была оценка эффектов увлажнения, освещения, половой принадлежности и этапа онтогенеза на концентрацию каннабидиола и $\Delta^{9}$-тетрагидроканнабинола у генотипически разнообразных образцов конопли для формирования оптимальной морфофизиологической и агрохозяйственной модели сорта, специализированного для получения КБД в условиях открытого грунта. Материалом служили генотипически оригинальные, пространственно разделенные популяции растений конопли (род Cannabis L.), произрастающие in situ. Исследования проводили в 2008-2011 годах. На территории четырех федеральных округов России выбрали 128 популяций, из которых в 52 изучали эффект фактора затенения, в 58 - фактора избытка увлажнения. В каждой популяции рендомизированно и репрезентативно собирали растения, формировали общие пробы. Образцы отбирали в период начала бутонизации и цветения - начала созревания семян. Пробы для биохимического анализа представляли собой измельченную воздушно-сухую массу верхушечных частей растений в следующих вариантах: с соцветиями, без соцветий, женские растения, мужские растения. Раздельно анализировали соцветия (генеративные части) и только листья (вегетативные части) у двух половых типов конопли. Генотипические различия изученных образцов по содержанию КБД были статистически значимы $(\mathbf{p}=\mathbf{0 , 0 5})$. Половой полиморфизм по признаку содержания КБД и ТГК оказался статистически недостоверным. В обеих условных группах мужских и женских растений содержание КБД было приблизительно равным от бутонизации до созревания семян. От стадии бутонизации до созревания семян количество КБД увеличивалось в 2 раза. Генеративные части растений содержали значимо больше КБД, чем вегетативные. К фазе бутонизации у растений разных половых типов в генеративных частях было в 2 раза болыше КБД, чем ТГК. Максимум КБД накапливался в генеративных частях до начала созревания семян. Накопление КБД в растениях любых половых типов значимо зависело от интенсивности естественного освещения: нарушение освещения приводило к снижению количества КБД. Фактор избытка (или дефицита) естественного увлажнения на стадии взрослого растения достоверно не влиял на аккумуляцию КБД. В отличие от двудомных сортов конопли зернового и масличного направлений, растения условных половых типов (матерки и поскони) могут быть в равной мере использованы для получения КБД. Матерка должна иметь длительный период бутонизации-полного цветения в условиях минимального количества пыльцы с последующим поздним созреванием семян. Цветение и максимальное пыление поскони должно быть поздним, поскольку дефицит пыльцы способствует накоплению КБД у женских растений. Растения КБД-сорта должны иметь максимальную массу и размер длительно бутонизирующих и цветущих минимально облиственных соцветий.

Ключевые слова: Cannabis sativa L., Cannabis ruderalis L., конопля, половые типы, фитоканнабиноиды, каннабидиол, $\Delta^{9}$-тетрагидроканнабинол, модель CBD-сорта, селекция.

Конопля (Cannabis L.) - одна из самых древних сельскохозяйственных культур (1). В силу различных факторов посевы промышленной конопли в СССР и Российской Федерации регрессировали с 1 млн га в 1940-х до 150 тыс. га в 1980-х годах и в настоящее время составляют около

Выполненная работа соответствовала тематическому плану ВИР по теме № 0662-2019-0001 «Коллекция масличных и прядильных культур ВИР (изучение и расширение генетического разнообразия масличных и прядильных культур)». 
15 тыс. га. На фоне снижения объемов культивирования конопли в Российской Федерации отмечалась тенденция структурного увеличения доли синтетических наркотиков в незаконном обороте, под которые маскировались различные психоактивные вещества (2).

Современная переработка конопли - это не только текстиль различного назначения и костра, но и инновационное использование семян и масла для функционального питания и фармации. С 1994 по 2017 год в странах ЕС посевная площадь сортов конопли для получения семян, масла и волокна увеличилась с 8 до 33 тыс. га. Только во Франции в 2017 году под посевы было занято 18 тыс. га. В Прибалтийских государствах ЕС в 2018 году площади составили около 14 тыс. га. В Канаде конопля ежегодно высевается более чем на 15 тыс. га. В 2011 году в США ежегодный объем официально импортируемых продуктов промышленной конопли оценивался в 11 млн долларов $(3,4)$, а с 2018 года в стране были возобновлены посевы культуры.

Соцветия и листья конопли содержат свыше 60 различных фитоканнабиноидов - терпенфенольных соединений, производных 2-замещенного 5-амилрезорцина. Предшественником всех фитоканнабиноидов служит каннабигероловая кислота. Она трансформируется в каннабихроменовую, каннабидиоловую и $\Delta^{9}$-тетрагидроканнабиноловую кислоты, которые преобразуются в каннабиноиды. Каннабидиоловая и $\Delta^{9}$-тетрагидроканнабиноловая кислоты относятся к основным. Их синтез в растении обусловлен генетически. За психотропный эффект наркотических средств отвечает $\Delta^{9}$-тетрагидроканнабинол (ТГК, $\Delta^{9}$-tetrahydrocannabinol, THC), способный избирательно связываться со структурами головного мозга - каннабиноидными рецепторами. В отличие от ТГК, каннабидиол (КБД, cannabidiol, CBD) обладает выраженным терапевтическим и седативным эффектом для человека. Влияние его концентрации обратно пропорционально психотропности ТГК (5).

В ряде стран Европы и США практикуется применение каннабидиола как супрессанта симптомов рвоты и тошноты, спровоцированных антиканцерогенным лечением, а также против потери веса у больных СПИДом. Каннабидиол используется для лечения психоневротических расстройств, ревматизма, глаукомы, рассеянного склероза, алкоголизма, астмы, для достижения обезболивающего эффекта $(1,6)$, при снижении аппетита, нарушениях вынашивании плода у беременных, для стимуляции лактации, при нейродегенеративных состояниях $(7,8)$ и в противоопухолевой терапии (9-11). Каннабиноды перспективны в качестве замены опиатов $(12,13)$. Опубликованы новые данные, касающиеся их применения в терапии онкологических заболеваний и при болезни Альцгеймера, а также сведения о взаимосвязи эндоканнабиноидной системы и регуляции тока внутриглазной жидкости, о сосудорасширяющих и нейропротекторных эффектах каннабиноидов (14).

В литературе приводятся результаты оценки вегетативно размножаемых в закрытом грунте линий (хемотипов) конопли на содержание одного из каннабиноидов, сведения о генотипировании сортообразцов для дифференциации технотипов и хемотипов, о различиях в метаболизме каннабиноидов у сортов масличного и прядильного направлений и хемотипов (типа Purple Kush) $(15,16)$. Биохимические маркеры используются для отбора растений с максимальным содержанием терпенов и КБД (хемотип III типа), культивируемых в закрытом грунте (17).

Динамику содержания основных каннабиноидов в растениях коноп- 
ли ранее изучали на десяти районированных сортах в фазу всходы-цветение на ярусно дифференцированных листьях, что скорее имеет значение для экспертно-криминалистической работы $(18,19)$. Другие исследования (20) сфокусированы на минимизации содержания ТГК (менее 0,01 \%) у гибридных популяций $\mathrm{F}_{1}$ и $\mathrm{F}_{2}$ для селекции однодомной конопли. Сведения о накоплении каннабидиола в онтогенезе растений технической (промышленной) конопли обобщены на основании теоретических расчетов и изучения лишь трех однодомных сортов (21). Работы имели узкую специфику, были направлены на изменение районированного однодомного сорта иной специализации селекционными методами и не релевантны в отношении других технотипов промышленных сортов, а также не охватывали доступного генотипического разнообразия рода Cannabis L.

Сохраняемые в большинстве исследовательских центров генетические ресурсы конопли весьма немногочисленны, генотипически однородны $(22,23)$ и мало изучены в отношении хозяйственно значимых признаков. Недостаток данных по оценке генетически разнообразного исходного материала становится ограничением при создании сортов с целью получения каннабидиола (КБД-сорта).

Для успешной селекции конопли на высокое содержание КБД и редуцированное - ТГК требуется эффективная стратегия, обеспечивающая создание сортов с биохимически, морфологически, технологически специализированными и генетически стабильными признаками. Существенный элемент такой стратегии - отбор исходных образцов и адекватная оценка целевых признаков на этапах селекции.

В настоящей работе среди генотипического разнообразия обследованных природных популяций конопли впервые выделены формы фармацевтического направления использования (с контрастно высоким содержанием КБД - более 9 \% и следовым количеством основного психотропного каннабиноида ТГК) для культивирования в полевых условиях. Показано, что наибольшее количество КБД накапливается в растениях к началу созревания, а затенение приводит к уменьшению содержания этого фитоканнабиноида.

Цель нашего исследования - оценка эффектов увлажнения, освещения, половой принадлежности и этапа онтогенеза на содержание каннабидиола и $\Delta^{9}$-тетрагидроканнабинола у генотипически разнообразных образцов конопли для формирования оптимальной морфофизиологической и агрохозяйственной модели сорта, специализированного для получения КБД в условиях открытого грунта.

Методика. Отбор образцов проводили в 2008-2011 годах с учетом естественного переопыления как значимого критерия для разделения популяций (24). Исходным материалом служили генотипически оригинальные, пространственно разделенные (вне досягаемости перекрестного переопыления) популяции растений конопли (род Cannabis L.), произрастающие in situ на территории четырех федеральных округов России.

Для исследования выбрали 128 популяций, из которых у 52 изучали эффект фактора затенения, у 58 - фактора избытка увлажнения. В первом случае в каждой из 52 популяций, произрастающих под пологом леса, собирали не менее 10 растений с незатененных участков и объединяли в единую пробу для популяции. Так же формировали объединенную пробу из растений, вегетировавших под кронами деревьев. В 58 популяциях, в каждой из которых часть растений обитали у кромки воды естественного водоема (река), а остальные - на возвышенности (вне досягаемости избы- 
точной воды), аналогичным образом формировали объединенные пробы. Все растения собирали рендомизированно и репрезентативно в период от начала бутонизации и цветения до начала созревания семян, чтобы нивелировать климатическую и временну́ю вариансы в соответствии с принципом «при прочих равных условиях (ceteris paribus)».

Для определения каннабиноидов верхушечные части растений высушивали до воздушно-сухого состояния и измельчали. Образцы готовили в следующих вариантах: с соцветиями, без соцветий, женские растения, мужские растения. Раздельно анализировали соцветия (генеративные части) и только листья (вегетативные части) у двух половых типов конопли. Динамику накопления каннабидиола и $\Delta^{9}$-тетрагидроканнабинола исследовали от начала цветения мужских растений (посконь), бутонизация у которых обычно наступала раньше, чем у женских (матерка), до начала усыхания поскони и начала созревания первых семян в основании соцветия женских растений.

Пробы для газохроматографического анализа каннабидиола и $\Delta^{9}$ тетрагидроканнабинола готовили по методикам, принятым в экспертнокриминалистической практике. Измерения проводили на хроматографе CHROM 5 («Bruker», Чехия) стандартной комплектации с пламенно-ионизационным детектором согласно рекомендациям производителя. Данные о содержании каннабиноидов в пробе получали в 3 аналитических повторностях.

Статистическую интерпретацию данных осуществляли с использованием дисперсионного (ANOVA) и корреляционного анализа в программе Statistica 10.0 («StatSoft, Inc.», США). На рисунках приведены средние значения $(M)$ и стандартные отклонения $( \pm \mathrm{SD})$ при 95 \% уровне значимости. Рассчитанные коэффициенты корреляции (простая линейная корреляция) считали значимыми при р $<0,05$.

Результаты. Изученные образцы конопли достоверно $(\mathrm{p}=0,05)$ различались по содержанию каннабиноидов. От начала стадии бутонизации образцов до начала созревания семян содержание КБД в растениях увеличивалось более чем в 2 раза (рис., А), причем генеративные части растений содержали в 2 раза больше КБД, чем вегетативные (см. рис., Д). По количеству ТГК различия между частями растений были менее контрастными (см. рис., Е).

Разнообразие половых типов у конопли (обычно до семи типов в популяции) мы условно сократили до двух групп - тип матерки (однополая матерка, однодомная матерка, маскулинизированная матерка) и тип поскони (обычная однополая посконь, однодомная посконь, феминизированная посконь). Влияние половой принадлежности на количество КБД и ТГК оказалось статистически недостоверным (см. рис., В, Г). У обеих групп (матерки и поскони) содержание КБД было приблизительно равным. С учетом воздействия внешних факторов можно отметить, что к началу бутонизации у растений конопли разных половых типов количество КБД в генеративных частях было в 2 раза больше, чем ТГК. Однако максимум КБД накапливается в генеративных частях к началу созревания семян (см. рис., А, В).

Эдафический фактор избытка или дефицита естественного увлажнения значимо не влиял на количество ТГК и КБД (см. рис., Ж, 3), в то время как затенение приводило к достоверному $(\mathrm{p}=0,05)$ снижению содержания КБД в растениях (см. рис., И), но не оказывало существенного влияния на концентрацию ТГК (см. рис., К). 
На изученном генотипическом разнообразии образцов была установлена слабая отрицательная корреляционная зависимость между содержанием КБД и ТГК в соцветиях конопли $(r=-0,16)$. Следовательно, перспективы селекции образцов конопли с контрастно высоким содержанием каннабидиола и значимо низким (следовым) количеством ТГК очевидны. С прохождением фаз от бутонизации к созреванию семян содержание каннабидиола в растениях конопли повышалось $(r=0,35)$. Коррелятивная связь содержания КБД с половым типом растений оказалась слабой $(r=-0,1)$.

В настоящее время в Российской Федерации в Государственном реестре селекционных достижений, допущенных к использованию, не включены сорта, специализированные для получения физиологически активных функциональных ингредиентов и продуктов. Нет промышленных сортов для получения каннабидиола, источником которого пока что служат вегетативно размножаемые в защищенном грунте гибриды. Очевидно, это может быть не единственным способом возделывания конопли для получения фитоканнабидиола. Размножаемые семенами двудомные и однодомные специализированные сорта конопли для получения КБД могут успешно возделываться в условиях открытого грунта. Мы показали, что нарушение естественного освещения (затенение) растений конопли снижает количество КБД в них более чем в 2 раза. Следовательно, рентабельное возделывание конопли в защищенном грунте для получения КБД лимитировано качеством и количеством освещения.

В России и соседних странах селекция конопли проводилась исключительно на элиминацию всех каннабиноидов, в том числе КБД, у 97,8-99,6 \% растений сорта. И.М. Лайко с соавт. (25) утверждают, что отсутствие КБД у промышленного сорта может быть перспективным направлением. Наша точка зрения не совпадает с этой позицией. Как было показано ранее (5), каннабидиол не является значимым в психотропном эффекте конопли и антагонистичен психотропному действию ТГК. Снижение общего содержания каннабиноидов у сортов в 1980-2000 годах и продолжающаяся селекция на достижение следовых количеств каннабиноидов, вплоть до их полной элиминации у промышленной конопли, не предотвратили резкого падения посевных площадей культуры в России и роста числа наркозависимых.

В своей работе мы вели поиск перспективного селекционного материала с функционально ориентированным составом каннабиноидов и морфологией растения (максимум КБД, минимум ТГК, минимальная облиственность, максимальный размер соцветия, адаптированные периоды бутонизации-созревания семян), тогда как предшествующие работы (21) были проведены на селекционных отборах для одного однодомного универсального сорта.

Поддержание признака однодомности у районированных сортов (содержание обычной поскони 0 \%) требует значимых затрат и считается одной из основных селекционно-семеноводческих задач в работе с однодомной коноплей (20). Однако мы считаем, что для реализации возможности продуктивного использования как женских, так и мужских растений у двудомного сорта промышленной конопли концепция производственной функциональности различных половых типов сорта, их биохимических и агрономических свойств может быть перестроена. В отличие от существующих двудомных универсальных сортов (одновременно волокнистого, зернового и масличного направлений использования), растения условных по- 
A

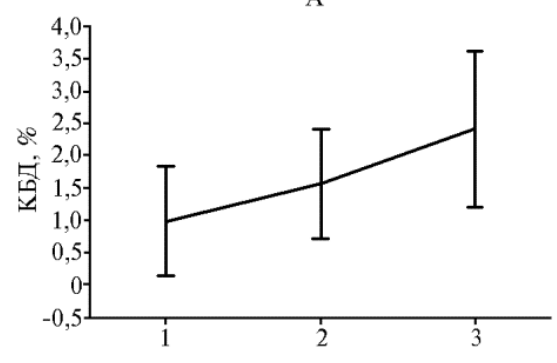

B

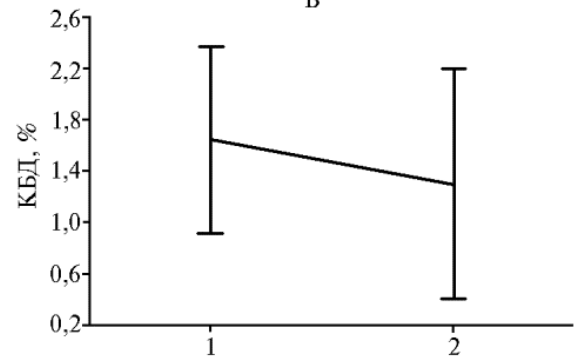

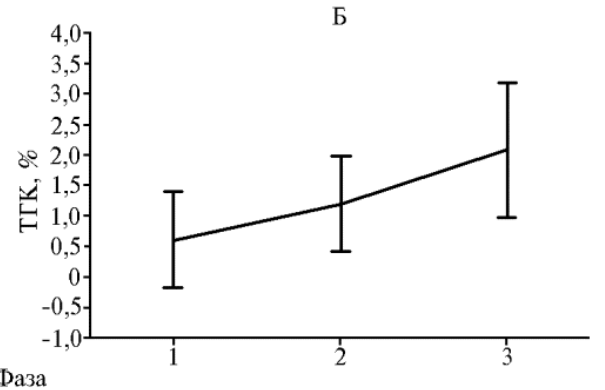

$\Gamma$

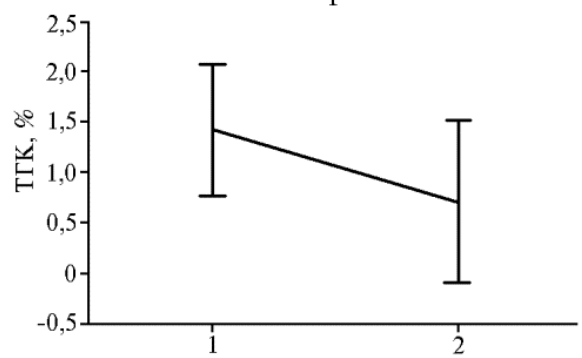

E

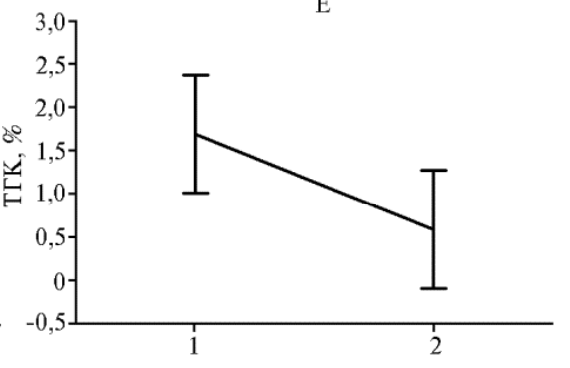

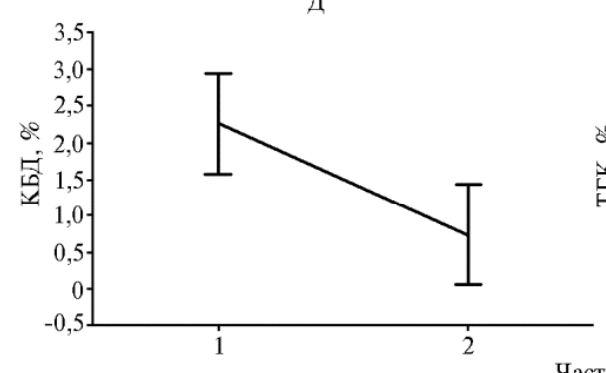

Часть растения
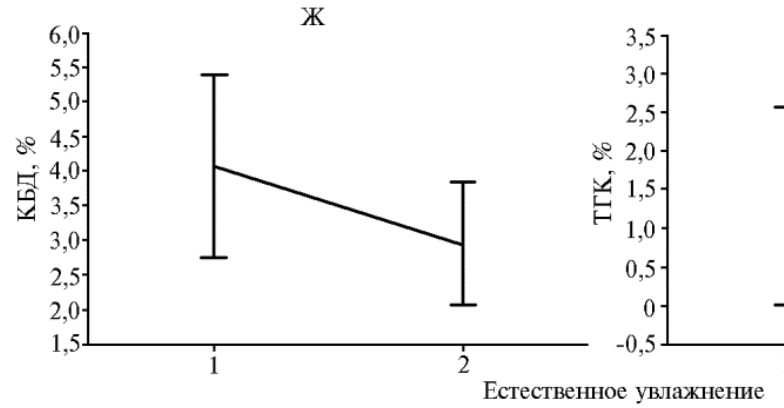

3

И

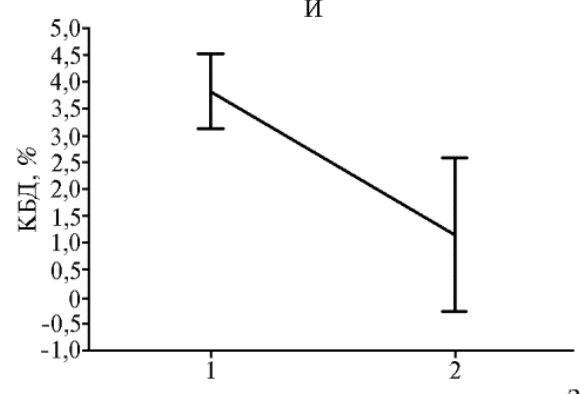

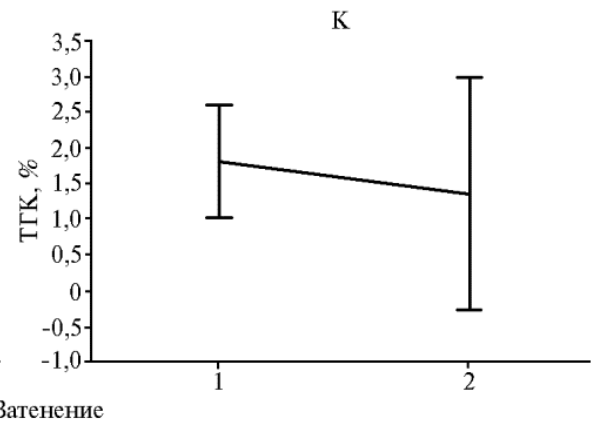

Содержание каннабидиола (КБД) и $\Delta^{9}$-тетрагидроканнабинола (ТГК) в растениях конопли (Cannabis L.) в зависимости от различных факторов: А, Б - фаза вегетации (1 - бутонизация, 2 - цветение, 3 - созревание), В, Г - половой тип $(1-$ женские растения, $2-$ мужские 
растения), Д, Е - генеративные и вегетативные части (1 - соцветия, 2 - вегетативная масса), Ж, 3 - естественное увлажнение (1 - дефицит, 2 - избыток), И, К - затенение (1 отсутствует, 2 - присутствует) (ANOVA, $M \pm \mathrm{SD}$; различные регионы Российской Федерации, 2008-2011 годы; описание сбора и подготовки образцов см. в разделе «Методика»).

ловых типов могут в равной мере применяться для продукции максимального количества КБД.

Оценку селекционного материала и дифференциацию образцов конопли по количеству КБД следует начинать с фазы бутонизации. Однако формы с контрастным содержанием ТГК можно выделить с наступлением фазы созревания семян у основания соцветий. Фенологическая фаза начала созревания семян у КБД-сортов должна быть максимально сдвинута к сроку уборки урожая.

Полученные нами данные отличаются от ранее опубликованных результатов опытов с сортами однодомной среднерусской конопли (18). О.Н. Зеленина с соавт. $(18,19)$ изучали листья сортов в период от всходов до цветения. Мы показали, что максимальное количество КБД накапливается с наступлением полного цветения растений, тогда когда содержание ТГК в этот период еще мало. Количество ТГК может возрастать позже, с приближением фазы созревания семян. В период цветения женских растений само соцветие продолжает расти и увеличиваться в размерах, в его нижних частях начинается созревание семян, в срединных - отмечается бутонизация. В указанные периоды роста количество листьев на растении уже практически сформировано. С началом бутонизации в соцветиях образуется значительное количество смолистых веществ, функция которых улавливать мигрирующую в воздухе пыльцу, необходимую для завязывания семян. В это время содержание каннабидиола в соцветии достигает максимума, а с начала созревания семян его количество снижается. Исходя из перечисленных фактов, мы сделали вывод о необходимости селекционного увеличения размеров длительно цветущего соцветия как матерки, так и поздно зацветающей поскони у специализированного сорта. Цветение и максимальное пыление поскони должно быть поздним, поскольку дефицит пыльцы способствует накоплению КБД у женских растений. Анализ транскриптома железистых трихом у цветов конопли (26), которые указаны авторами как основное место синтеза каннабиноидов, показал высокую активацию поликетидциклазоподобных ферментов (polyketide cyclase-like enzymes) во время массовой бутонизации и цветения. Соответствующий транскрипт был обнаружен в высокоэкспрессивном состоянии в трихомах, что подтверждает пик ферментативной активности в соцветиях в указанный период. Эти сведения согласуются с нашими выводами: при длительном цветении большого количества соцветий обеспечивается высокое накопление фитоканнабидилола.

Для селекции конопли прядильного и зернового направлений использования соотношение половых типов имеет приоритетное значение, поскольку условные группы поскони и матерки обычно различаются по ряду признаков. Мы показали, что у сортов конопли, ориентированных на максимальный урожай КБД, обе условные половые группы в равной степени могут быть продуцентами этого каннабиноида. Из результатов исследования динамики накопления КБД и ТГК растениями конопли различных половых типов следует, что для создания специализированного КБДсорта нужно отбирать формы, у которых растения поскони поздно зацветают и не отмирают до уборки, оставаясь равным с растениями матерки 
источником КБД. При этом растения типа матерки тоже должны иметь длительный период, включающий начало бутонизации-полное цветение, но характеризоваться более поздним началом созревания семян. Растения специализированных сортов следует убирать сразу после наступления полного цветения у половых типов, но до начала созревания семян, поскольку в период полного цветения КБД в соцветиях уже достаточно много, а ТГК значимо мало. К тому же количество ТГК может возрастать по мере приближения фазы формирования семян. Фаза созревания семян у КБДсортов должна наступать максимально поздно и по срокам приближаться к уборке урожая.

Концепция морфологического строения растений КБД-сорта конопли также отлична от таковой для сортов универсального и двустороннего (прядильного) направления использования. Растения специализированного сорта для получения КБД должны иметь максимальные массу и размер соцветий и максимально уменьшенную в объеме вегетативную часть. Это согласуется с предшествующими исследованиями (27), где автор приходит к выводу об увеличении репродуктивных частей соцветий при минимизации стеблей у специализированных сортов для получения масла и химических соединений. Габитус растений специализированного сорта - длительно цветущие соцветия большого размера с минимальной облиственностью, поскольку содержание КБД в листьях значимо меньше.

Содержание каннабидиола в соцветии (\%) у образцов конопли (Cannabis L.), выделенных для использования в селекции сортов фармацевтического направления в популяциях из разных регионов Российской Федерации (2008-2011 годы)

\begin{tabular}{l|l|l|c}
\hline $\begin{array}{l}\text { № в интродукцион- } \\
\text { ном каталоге ВИР }\end{array}$ & Вид & Экотип & Каннабидиол \\
\hline 141445 & C. sativa & Северный & 2,40 \\
141446 & C. sativa & Северный & 1,91 \\
141447 & C. sativa & Северный & 1,87 \\
141448 & C. sativa & Среднерусский & 2,99 \\
141855 & C. sativa & Среднерусский & 3,96 \\
141856 & Предположительно C. sativa $\times$ C. ruderalis & Среднерусский & 9,78 \\
141451 & Предположительно C. sativa $\times$ C. ruderalis & Среднерусский & 2,76 \\
141864 & Предположительно C. sativa $\times$ C. ruderalis & Среднерусский & 2,53 \\
\hline
\end{tabular}

Наши исследования показали, что образцы, которые могут быть отнесены к различным видам и экотипам конопли, накапливали каннабидиол в значительных количествах. Например, образец 141855 содержал 3,96 \% КБД, а 141856 - более $9 \%$ (табл.).

Полученные нами данные принципиально отличны от опубликованных ранее, поскольку мы предложили модель сорта промышленной конопли фармацевтического направления использования для культивирования в полевых условиях, а не в теплицах и гроубоксах, как это практикуется за рубежом с сортами и вегетативно размножаемыми гибридами, не входящими в официальный список Евросоюза. Следует принять во внимание, что специализированных КБД-сортов для использования в открытом грунте в настоящее время нет, но потребность в них достаточно высока. Ранее созданные сорта универсального типа для открытого грунта не отвечают задачам производства как фитоканнабидиола, так и функциональных пищевых ингредиентов. Уточнение модели специализированного сорта необходимо для постановки цели и формирования стратегии селекции конопли для фармацевтического использования, конкретизации перечня селекционно значимых признаков, целенаправленного изучения генотипического разнообразия исходного материала, формирования признаковой кол- 
лекции и создания продвинутого селекционного материала. С учетом этого мы планируем продолжить селекционно-генетические исследования по созданию сорта конопли фармацевтического направления использования.

Таким образом, с начала бутонизации конопли растения разных половых типов накапливают в генеративных частях в 2 раза больше каннабидиола (КБД), чем $\Delta^{9}$-тетрагидроканнабинола (ТГК). Максимальное количество КБД обнаруживается к началу созревания. Обе условные группы растений (матерки и поскони) содержат приблизительно равные количества КБД. Фактор избытка или дефицита естественного увлажнения в период от бутонизации до начала созревания семян значимо не влияет на накопление ТГК и КБД. Затенение растений приводит к снижению содержания КБД. Особенности морфологии растений КБД-сорта конопли большая масса и размер соцветия при максимально уменьшенной в объеме вегетативной части. В результате проведенных исследований нами выделены образцы с ценным соотношением КБД/ТГК, которые будут использованы в селекции конопли при создании специализированных сортов, не обладающих специфичной психотропной активностью.

Авторы выражают искреннюю благодарность Государственному антинаркотическому комитету (ГАК) и Федеральной службе по контролю за оборотом наркотиков (ФСКН) за поддержку в проведении исследований.

\footnotetext{
${ }_{1}^{1}$ ФББНУ ФИЦ Всероссийский институт

генетических ресурсов растений им. Н.И. Вавилова,

190000 Россия, г. Санкт-Петербург, ул. Большая Морская, 42-44,

e-mail: s.grigoryev@vir.nw.ru $\bowtie$;

2 ФГАОУ ВО Санкт-Петербургский политехнический

университет им. Петра Великого,

195251 Россия, г. Санкт-Петербург, ул. Политехническая, 29,

e-mail: elkv@mail.ru
}

Sel'skokhozyaistvennaya biologiya [Agricultural Biology], 2020, V. 55, № 1, pp. 107-117

Поступила в редакцию

22 августа 2019 года

\section{EVALUATION OF FACTORS HAVING AN EFFECT ON CANNABIDIOL AMOUNT IN Cannabis sativa $\mathrm{L}$.}

\section{S.V. Grigoryev ${ }^{1}$, K.V. Illarionova ${ }^{2}$}

${ }^{1}$ Federal Research Center Vavilov All-Russian Institute of Plant Genetic Resources, 42-44, ul. Bol'shaya Morskaya, St. Petersburg, 190000 Russia, e-mail ser.grig@mail.ru ( $\square$ corresponding author);

${ }_{2}^{2}$ Peter the Great St. Petersburg Polytechnic University, 29, ul. Politechnicheskaya, St. Petersburg, 195251 Russia, e-mailelkv@mail.ru

ORCID:

Grigoryev S.V. orcid.org/0000-0001-7670-4360 Illarionova K.V. orcid.org/0000-0002-2563-6094

The authors declare no conflict of interests

Acknowledgements:

The authors are sincerely grateful to the State Anti-Drug Committee and the Federal Drug Control Service of the Russian Federation for their support in conducting research.

The work corresponds to the VIR thematic plan on the topic No. 0662-2019-0001 "VIR Collection of oilseeds and spinning crops (genetic diversity research and improvement)".

Received August 22, 2019

doi: 10.15389 /agrobiology.2020.1.107eng

\section{Abstract}

Industrial hemp is a multipurpose crop, supplying fibers, seeds, and pharmaceuticals. The non-psychotropic cannabidiol (CBD) derived from hemp is a promising pharmaceutical raw material. It shows no psychotropic effects, is not listed in UN Single Convention on Narcotic Drugs, but demanded for the production of medicine products. Regretfully, there are no domestic cultivars of hemp in Russia specialized in phytocannabidiol. Currently, there is a big need in industrial varieties of pharmaceutical specialization (CBD-cultivars). This paper is the first to report on selection of the accessions with high $\mathrm{CBD}$ content (above $9 \%$ ) and trace amounts of $\Delta^{9}$-tetrahydrocannabinol (THC), the main psychotropic cannabinoid, among the studied genotypic diversity of hemp plants. 
The objective of the study was the assessment of the effects of field watering, lighting conditions, sexual type of plants and stage of ontogenesis on CBD and THC accumulation on a broad in situ genotypic diversity of Cannabis L. germplasm accessions in order to form the optimal morphophysiological and agronomical model of CBD-producing cultivar (ideotype) well adapted to field growing. Cannabis populations in situ, genotypically original, spatially separated (and, thus, not undergone to random cross pollination), were surveyed in 2008-2011 in four Russian regions. A total of 128 populations were selected for the research; among them, 52 populations were studied for the effect of shading, and 58 for the moisture excess/deficit. For each population, plants (not less than $n=10$ per each variant, i.e. shading vs. lighting, and moisture excess vs. deficit) were collected randomly and representatively to form summarized sample, and then analyzed to reveal the effect of the said factors. The plants were collected from initial budding and flowering of male plants, up to the moment when fimbles have just begun to dry out and the first seeds at the basal parts of female inflorescences have started to ripen. Air-dry samples (with and without inflorescences, female plants, male plants) were crushed and biochemically analyzed. Inflorescences (generative parts) and only leaves (vegetative parts) of the two conventional sexual types were analyzed separately. The analysis of the CBD and THC contents in the studied accessions revealed a statistically significant $(p=0.05)$ genotypic variability for CBD between the samples. Natural sexual polymorphism in the content of $\mathrm{CBD}$ and THC is statistically unreliable. Both male and female plants contain approximately equal CBD concentrations from the budding time until the seed ripening. THC amount was insignificantly increased in female plants. From the budding phase until the start of seed ripening, plants increase their CBD content more than twice. From the budding phase until the seed ripening, CBD amount in inflorescences is significantly thrice more than in vegetative parts. The difference in THC content is significant as well, but not so noteworthy. By the start of budding of different sexual types CBD content in generative parts is twice as high as that of THC. CBD accumulation reaches its maximum in generative plant parts by the time when seed ripening starts initially. The effect of shading on plants of any sexual type has shown that CBD content significantly responds to the exposure and intensity of natural lighting. Any breach in daylight illumination will reduce the CBD content. The factor of excessive/deficient natural moistening has no significant effect on CBD and THC accumulation in plants, regardless of the development phase of an adult plant of any sexual type. Unlike to dioecious cultivars specialized for seed/oil production, both female and male plants may be used for CBD production. Female plants must have extended time of budding-full flowering in conditions of reduced amounts of pollen in air and deferred seed ripening. Flowering and maximum pollen production from male plants must be deferred, because the lack of pollen in field promotes CBD formation in female inflorescences. CBD cultivar plants should have a maximum inflorescence size, a maximum budding and flowering period, and a minimum foliage.

Keywords: Cannabis sativa L., C. ruderalis L., hemp, plant sexual types, phytocannabinoids, cannabidiol, $\Delta^{9}$-tetrahydrocannabinol, CBD-cultivar ideotype, breeding.

\section{REF E R E N C ES}

1. Clarke R.C., Merlin M.D. Cannabis: evolution and ethnobotany. University of California Press, Berkeley, Los Angeles, London, 2013.

2. Filippova N.V., Baryl'nik Yu.B., Deeva M.A., Sobakina O.Yu. Narkologiya, 2015, 14, 8(164): 86-90 (in Russ.).

3. Yang Y., Lewis M.M., Bello A.M., Wasilewski E., Clarke H.A., Kotra L.P. Cannabis sativa (hemp) seed $\Delta^{9}$-tetrahydrocannabinol and potential overdose. Cannabis and Cannabinoids Research, 2017, 2(1): 274-281 (doi: 10.1089/can.2017.0040).

4. Fletcher R.S., McKay J. Industrial hemp Cannabis cultivars and seeds with stable cannabinoid profiles. United States Patent Application Publication. Pub. No.: US 2017/0339907 A1. New West Genetics, Ft. Collins, CO (US). Nov. 30, 2017.

5. Grotenhermen F., Karus M. Industrial hemp is not marijuana: comment on the drug potential of fiber Cannabis. Journal of the International Hemp Association, 1998, 5(2): 96-99.

6. Pertwee R. The therapeutic potential of Cannabis and cannabinoids for multiple sclerosis and spinal injury. Journal of the International Hemp Association, 1999, 4(1): 1-7.

7. Fernández-Ruiz J., Sagredo O., Pazos M.R., García C., Pertwee R., Mechoulam R., MartínezOrgado J. Cannabidiol for neurodegenerative disorders: important new clinical applications for this phytocannabinoid? British Journal of Clinical Pharmacology, 2013, 75(2): 323-333 (doi: 10.1111/j.1365-2125.2012.04341.x).

8. Boehnke K.F., Scott J.R., Litinas E., Sisley S., Williams D.A., Clauw D.J. Pills to pot: observational analyses of cannabis substitution among medical cannabis users with chronic pain. Journal of Pain, 2019, 20(7): 830-841 (doi: 10.1016/j.jpain.2019.01.010).

9. McAllister S.D., Christian R.T., Horowitz M.P., Garcia A., Desprez P.Y. Cannabidiol as a novel inhibitor of Id-1 gene expression in aggressive breast cancer cells. Molecular Cancer Ther- 
apeutics, 2007, 6(11): 2921-2927 (doi: 10.1158/1535-7163.MCT-07-0371).

10. McAllister S.D., Soroceanu L., Desprez P.Y. The antitumor activity of plant-derived nonpsychoactive cannabinoids. Journal of Neuroimmune Pharmacology, 2015, 10(2): 255-267 (doi: 10.1007/s11481-015-9608-y).

11. Molchanova A.Yu., Ulashchik V.S. Zdravookhranenie, 2015, 2: 32-40 (in Russ.).

12. Reiman A., Welty M., Solomon P. Cannabis as a substitute for opioid-based pain medication: patient self-report. Cannabis and Cannabinoid Research, 2017, 2(1): 160-166 (doi: 10.1089/can.2017.0012).

13. Khan S.P., Pickens T.A., Berlau D.J. Perspectives on cannabis as a substitute for opioid analgesics. Pain Management, 2019, 9(2): 191-203 (doi: 10.2217/pmt-2018-0051).

14. Petrov S.Yu., Vostrukhin S.V., Safonova D.M. Natsional'nyi zhurnal glaukoma, 2016, 15(4): 95100 (in Russ.).

15. Russo E.B. Taming THC: potential cannabis synergy and phytocannabinoid-terpenoid entourage effects. British Journal of Pharmacology, 2011, 163(7): 1344-1364 (doi: 10.1111/j.14765381.2011.01238.x).

16. Chandra S., Lata H., ElSohly M.A., Walker L.A., Potter D. Cannabis cultivation: methodological issues for obtaining medical-grade product. Epilepsy \& Behavior, 2017, 70: 302-312 (doi: 10.1016/j.yebeh.2016.11.029).

17. Lewis M.A., Russo E.B., Smith K.M. Pharmacological foundations of Cannabis chemovars. Planta Med., 2018, 84(4): 225-233 (doi: 10.1055/s-0043-122240).

18. Zelenina O.N., Smirnov A.A. Niva Povolzh'ya, 2010, 4(17): 16-20 (in Russ.).

19. Zelenina O.N., Serkov V.A., Smirnov A.A. Vestnik Rossiiskoi akademii sel'skokhozyaistvennykh nauk, 2012, 4: 61-64 (in Russ.).

20. Serkov V.A., Klimova L.V., Danilov M.V. Niva Povolzh'ya, 2018, 3(48): 62-67 (in Russ.).

21. Mishchenko S.V., Laiko I.M. Nakoplenie kannabidiola v ontogeneze rastenii tekhnicheskoi (promyshlennoi) konopli. Plant Varieties Studying and Protection, 2018, 14(4): 390-399.

22. Welling M.T., Shapter T., Rose T.J., Liu L., Stanger R., King G.J. A belated green revolution for Cannabis: virtual genetic resources to fast-track cultivar development. Frontiers in Plant Science, 2016, 29(7): 1113 (doi: 10.3389/fpls.2016.01113).

23. Galasso I., Russo R., Mapelli S., Ponzoni E., Brambilla I.M., Battelli G., Reggiani R. Variability in seed traits in a collection of Cannabis sativa L. genotypes. Frontiers in Plant Science, 2016, 20(7): 688 (doi: 10.3389/fpls.2016.00688).

24. Shelenga T.V., Grigor'ev S.V., Illarionova K.V. Trudy po prikladnoi botanike, genetike i selektsii, 2012, 170: 208-215 (in Russ.).

25. Laiko I.M., Virovets V.G., Kirichenko A.I., Mishchenko S.V. V sbornike: Resursosberegayushchie ekologicheski bezopasnye tekhnologii proizvodstva i pererabotki sel'skokhozyaistvennoi produktsii [In: Resource-saving environmentally friendly technologies for the production and processing of agricultural products]. Saransk, 2014: 194-200 (in Russ.).

26. Gagne S.J., Stout J.M., Liu E., Boubakir Z., Clark S. M., Page J.M. Identification of olivetolic acid cyclase from Cannabis sativa reveals a unique catalytic route to plant polyketides. Proceedings of the National Academy of Science, 2017, 109(31): 12811-12816 (doi: 10.1073/pnas.1200330109).

27. Small E. Dwarf germplasm: the key to giant Cannabis hempseed and cannabinoid crops. Genetic Resources and Crop Evolution, 2018, 65(4): 1071-1107 (doi: 10.1007/s10722-017-0597-y). 